\title{
Reconciliation as a Political Discourse in Thailand's Current Conflicts
}

\author{
[Wichuda Satidporn and Stithorn Thananithichot ]
}

\begin{abstract}
Why do the Thai governments fail in solving a political conflict that has occurred since 2005 and maintaining peace through conducting a reconciliation process? This article answered this question through an assessment of how the term reconciliation has been defined and used by the Thai governments and political leaders during the past decades. This article argues that reconciliation in the Thai language is a term that has been dynamically interpreted, explained, and applied differently by policy makers, scholars, activists, and leaders of the conflicting groups. Several times, such an interpretation, explanation, and appliance have made this term a means to defeat the people of conflicting groups instead of a means of reconciling the society. The Thai old style of reconciliation, especially enacting laws to enforce peace and to use a coup in order to stop violence, is still implemented by political leaders. As a result, the political conflicts in this country sometimes have been paused but have never been solved until the present.
\end{abstract}

Keywords-reconciliation, political discourse, conflict, Thailand

\section{Introduction}

Since 2005, Thailand has experienced bloody confrontations between the government and the groups of protestor including the pro-Thaksin "red shirts" and the anti-Thaksin's "yellow shirts. Both movements grew rapidly with hundreds of thousands of citizens joining each camp's several demonstrations during the past decade. ${ }^{1}$ The red shirts include a large proportion of working-class and rural-based and the anti-military Thais. ${ }^{2}$ The supporters of the red shirts tend to be in the north and north-east of Thailand. ${ }^{3}$ The yellow shirts include pro-royal family, some middle class, and Bangkok's elites. ${ }^{4}$ The supporters of the yellow shirts tend to be southern-based Thais. ${ }^{5}$ In November 2013, this group newly formed the People's Democratic Reform Committee (PDRC), a coalition of the Democrat Party (DP), the PAD, and pro-military groups. For some scholars, these kinds of street politics have been a new political "culture" that makes Thailand very difficult to govern. ${ }^{6}$ Others see a growing trend of protest activism as evidence of a political awakening of the Thai rural masses. ${ }^{7}$ Whether these events are seen as threat or opportunity for the sustainable development of democracy in Thailand, reconciliation is one of the most important policies that Thai

Wichuda Satidporn

Srinakharinwirot University

Stithorn Thananithichot

King Prajadhipok's Institute governments during the past decade have paid attention to. During the past years, many alternatives for reconciliation from various countries were investigated by both domestic researchers and international experts and introduced to Thailand. Many of the scholars' and experts' recommendations were applied by Thai governments as a reconciliation policy, but none of them was successful.

Why do the Thai governments fail in maintaining peace through conducting a reconciliation process? This article answers this question through an assessment of how the term reconciliation has been defined and utilized by the Thai governments and political leaders during the past decades. This article argues that reconciliation in the Thai language is a term that has been dynamically interpreted, explained, and applied differently by policy makers, scholars, activists, and leaders of the conflicting groups. Many times, such an interpretation, explanation, and appliance have made this term a means to defeat the people of conflicting groups rather that a means of resolving the problems and reconciling the society. The Thai old style of reconciliation, especially enacting laws to enforce peace and to use a coup in order to stop violence, is still implemented by political leaders. As a result, the political conflicts in this country sometimes have been paused but have never been solved until the present.

\section{Reconciliation in Theory}

In this article, the concept of reconciliation is understood as that specific process that takes place during peace building, the way to create sustainable peace by identifying the root causes of the violent conflict and conducting activities to correct the problems that caused the conflict. ${ }^{8}$ In this regard, a reconciliation process should reduce hatred and create trust as well as restore relationships between those who have engaged in violent events. ${ }^{9}$ At its simplest, the goal of reconciliation is to find a way for the people who are former enemies to live together. ${ }^{10}$

It does not mean that the parties alienated by conflict have to love their former enemies, or forgive everything they did, or forget the past in any way, but to coexist with them, to develop the degree of cooperation necessary for sharing the future society with them, so that people in the society as a whole have better lives together than they have had separately. ${ }^{11}$

As a process, reconciliation is ideally utilized in order to prevent, once and for all, the use of the past as the seed of renewed conflict. ${ }^{2}$ The basic idea is to create a process that consolidates peace, breaks the cycle of violent conflict, and strengthens reintroduced or newly established democratic institutions. 13 Responsibility, truth acceptance, mercy, and the shared future of the society, therefore, are part of the process. ${ }^{14}$ Above all, the end goal is to construct a reconciled society where different people can coexist peacefully and be able to manage and transform conflict into better change. ${ }^{15}$ The successful reconciliation process requires both the victims and the offenders to gain renewed confidence in themselves and in each other. ${ }^{16}$ It also entails believing that an acknowledgement of the 
humanity of others is basic and one of the most important components of mutual trust that would help open the door for the gradual arrival of a desired and sustainable culture of non-violence. ${ }^{17}$ Moreover, in order for trust and confidence to be truly developed, a post-conflict society has to establish or reconstruct a minimum of functioning institutions - a non-partisan judiciary, an effective civil service and an appropriate legislative structure. ${ }^{18}$ It is this requirement that links a reconciliation policy to the many other tasks of a transition from violent conflict to sustainable peace.

\section{The Definitions of Reconciliation in the Thai Language and Context}

Before Thailand entered into the political conflict which began to erupt in 2005, the word "ปรองดอง [prong-dong]" (reconciliation), was often heard by Thais, and was derived from the royal speech of His Majesty King Rama 9. However, the exact definition of reconciliation that H.M. the king had used tends to mean “สามัคคีปรองดอง [sa-mak-kee-prong-dong]," which matches the English word "harmony" rather than "reconciliation." With reference to his majesty the king's royal guidance to demonstrators regarding the popular uprising on 14 October 1973, he stated the following: "Those who are older, they have experience. Young people have a body and brain power. If older and younger people harmonize ${ }^{19}$ and work in unison, the country and politics will go well." ${ }^{20}$ Further, on other occasions, such as the royal speech conferred upon the ceremonial guard parade on 3 December 1979 at Dusit Palace Royal Grounds, the king stated that "Thai forefathers were fighters who were harmonized and united $^{21}$ no matter what they did; as a result, our country has had the sovereignty and prosperity until today." 22 Another example is the royal speech given to the Thai people on the 1989 New Year's, stating that "harmony ${ }^{23}$ and generosity have been important traits of the Thai people to help the country remain independent and prosperous from the past to the present." ${ }^{24}$ In addition, a part of the royal guidance on the graduation ceremony of Chulalongkorn University on 13 July 1990 remarked that "everyone should be aware that every problem can be solved. If a person cannot solve a problem, more persons should collaborate in harmony ${ }^{25}$ so that such a problem will not be an obstacle to the success of work." 26 Additionally, the royal speech addressed to groups of persons on the occasion of H.M. the king's birthday on 4 December 1993 mentioned that "harmony or reconciliation ${ }^{27}$ does not mean that if one person says one thing, others have to say the same thing; otherwise, life will mean nothing. There must be differences among people. Even though sometimes there are different thoughts in their work, eventually they should work together in harmony.",28

According to the aforementioned definition, the word "ปรองคอง [prong-dong]" (reconciliation) that was used and understood in Thai society before 2005 matches the meaning defined in Royal Institute Dictionary as “ออมชอม [om-chom] ประนีประนอม [pra-nee-pranom] ยอมกัน [yom-kan] ไม่แก่งแย่งกัน [mai-kaeng-yaeng-kan] ตกลงกันด้วยความไกล่เกลี่ย [tok-long-kan-duay-kwam-klai-klia] ตกลงกันด้วยไมตรีจิต [tok-long-kan-duay-mai-tree-chit]," which is like many words in English in verb form, such as to harmonize, to be in harmony, to be reconciled, to compromise, to compound differences. In addition, since the late 1980s, when conflicts between the government sector, private sector, and civil society were progressing due to the Thai Government's guidelines for the economic development through the creation and implementation of mega projects that have had effects on society and the environment at large, the concepts of conflict resolution and conflict management have been addressed and adopted by many social science scholars in
Thailand. According to these concepts, the word “สันติวิธี [santi-witee]" (peaceful means) is used mostly as an instrument to deal with conflicts, while the words “สันติสภาวะ [santi-sapawa]" and "สันติสุข [santisuk]" (peace) are mentioned as the goal of conflict management. ${ }^{29}$ The word "ปรองดอง (prong-dong)," which corresponds to the English word "reconciliation," has been rarely used. When it is used, it seems to fit the English word "harmony" rather than "reconciliation." 30

However, since the military coup of September 19, 2006, led by General Sonthi Boonyaratglin and organized as the Council for Democratic Reform (CDR), which followed a year-long political crisis involving Thaksin, his allies, and political opponents, the term reconciliation has been mentioned and applied for solving the political conflict more often and with a more specific meaning than in the past. According to this paper's documentary research, reconciliation has been used and defined in the laws and policies implemented by several Thai governments and academic reports, aiming to understand the causes of the conflicts and to recommend appropriate solutions, with at least three meanings.

The first meaning of reconciliation is in accordance with the romantic view of Thai society as an amicable society, in which the Thai people live together in harmony and peacefully. The solution for the current political conflict, according to this view of reconciliation, has paid attention to the application of the principles and ideas that have already existed and acknowledged by the people in the Thai culture, such as the principles of Buddhism. Adopted by Thai scholars and activists in the peace studies field, the second meaning of reconciliation refers to the knowledge about conflict management and conflict resolution disseminated in Thailand before the current political conflict occurred in 2006. Reconciliation, according to this perspective, is the goal of conflict resolution methods such as negotiation, mediation, and dialogue. The third definition of reconciliation applied in Thailand is the one that specifically refers to the process that has been used in several countries in order to build peace. In this regard, reconciliation is not only a goal, but a means to bringing peace to the society through the process of dealing with the search for truth, social justice, sympathy and forgiveness, and accommodation between conflicting groups or people.

The first category of the meaning and understanding of reconciliation existed in most of the policy statements of the council of ministers delivered by the Thai governments to the parliament after the military coup on September $19^{\text {th }}, 2006$. For example, the government of General Surayud Chulanont indicated in the policy statement delivered to the National Legislative Assembly on November $3^{\text {rd }}, 2006$ the following:

"The Government is intent on building a strong society on the basis of virtue, a society in which all people live in peace and harmony, on the basis of the following policies:

Promote compassion and understanding, unity and reconciliation among the country's people so that they cooperate in the revitalization and rehabilitation of the nation on all fronts. In doing so, the Government shall draw lessons from past conflicts and failures to prevent and resolve such problems to foster understanding among the people. The Government shall also create a process for the resolution of problems, putting a premium on national harmony, while promoting the dissemination of examples of good cooperation that brings happiness to all segments of the Thai community. 
Formulate a social reform plan for shared happiness and national harmony on the basis of virtue. The Government is to draw up this plan together with the people, business, civil society, academia, media and religious institutions so as to build a caring, virtuous and democratic society, one in which the local community and civil society are strong. ${ }^{31,}$

According to the above statement, the term reconciliation, applied and announced by the government of General Surayud in order to solve Thailand's political conflict, which the CDR claimed as one of the main reasons for having a coup, was the same word as that used by the government of Thaksin when the National Reconciliation Commission (NRC) was established on March $28^{\text {th }}$, 2005 in order to solve the conflict in the deep southern provinces. ${ }^{32}$ This term was used by both governments with the same meaning as the word "solidarity" in English. For the government of General Surayud, reconciliation is the desired condition for the Thai people to live together. In other words, reconciliation is the ultimate goal that the government aims to achieve. In order to accomplish such a goal, the government of General Surayud applied conflict-resolution approaches and mechanisms proposed by scholars and activists in the field of peace studies. These approaches and mechanisms, as already discussed earlier in this article, were similar to those that had been previously used in Thailand for solving conflicts, especially between state agencies and involving groups or persons in the public policy process.

The conflict-resolution approaches and mechanisms applied by the government of General Surayud can be divided into two major methods. The first method was a public forum hosted and organized by the Ministry of Social Development and Human Security. The major attempt of this public forum made by the government was the creation of the so-called solidarity or conflict-resolution networks among ordinary people at the provincial level. The government of General Surayud expected that these networks could help to educate people about the political conflict and encourage them to work in cooperated in constructing unity and solidarity among the people in the nation. ${ }^{33}$ The second method focused on solving the conflict between political leaders. In this regard, the government of General Surayud appointed General Chavalit Yongchaiyudh, a former premier and the former deputy prime minister under the Thaksin government, as the government's president of the advisory team on national security and reconciliation. ${ }^{34}$ The government also supported the role of General Chavalit, who declared himself to represent a chain linking politicians and conflicting groups together, in coordinating backdoor negotiation or dialogue between the interim government and former prime minister Thaksin, who had been in exile since the 2006 military coup. ${ }^{35}$ However, the government of General Surayud failed to make the conflicting groups, especially the PAD leaders, accept the said conflict-resolution approaches and mechanisms. The words "reconciliation" and "solidarity" were perceived and interpreted by the opposition to the government as a compromised process among political leaders, who wished to protect only their own interests. In this regard, the real ultimate goal of the conflictresolution approaches and mechanisms used by the government of General Surayud was to turn back time by asking the conflicting groups to forget everything, as if nothing had happened to Thai politics during the past years. For the PAD leaders, this way of solving the political conflict was not different from what the previous interim governments established by the military coup did in the past, especially though the enactment of the amnesty law regarding the actions of all involved persons with no conditions. ${ }^{36}$ It was not a method that could solve any conflict problems; rather, the conflict only became compounded or was swept under the carpet.
After the 2007 Constitution was promulgated and the victory of the People Power Party (PPP), the TRT's proxy party, in the House of Representatives election on December $23^{\text {rd }}$, 2007, the word reconciliation was again mentioned in the policy statement delivered by Prime Minister Samak Sundaravej to the parliament. The key sentences stated the following:

"Over the next four years, the Government will look after both short and long-term problems, and is committed to the administration of the country under two main principles, which the Government is confident will contribute to the sustainability of the Thai economy and society, as well as establish confidence among Thai and foreign investors and the international community.

First is the fostering of reconciliation among all Thais, who will have to work together in guiding the country through various crises and building a secure foundation for the country's future. This fostering of reconciliation includes the important matter of resolving and healing the problems in the three southern border provinces, leading towards peaceful coexistence and harmony among the local people, and developing the economic potential of the country's South so that it becomes a significant national economic base..."

According to the policy statement of the government of Samak, the term reconciliation had been used with almost the same meaning as that used by the government of Surayud (i.e. solidarity). However, the implementation of this policy under the supervision of the government of Samak, in practice, was not the continued process of the reconciliation policy initiated during the period of Surayud's government. Rather, the first task of the government of Samak, in order to achieve its goal in fostering reconciliation among Thai citizens, was to propose a bill aiming to revise the 2007 Constitution. The government and the PPP leaders claimed that this process of constitutional amendment, because it provided a platform for all Thai citizens to work together in recommending a desired political structure for the country's future, would be a critical means for making the dream of reconciliation in Thai society come true. ${ }^{37}$ In contrast, for the PAD, the real purpose behind this attempt to revise the 2007 Constitution was no other than the reversal of the ban imposed on the executives of the disbanded TRT and the opportunity to acquit self-exiled Thaksin. ${ }^{38}$ This disagreement and heated debate regarding the constitutional amendment led to the reunion of the PAD to protest against the PPP-led government's proposal. The PAD protesters then extended their goal to topple the two governments led by Thaksin's proxy parties. The first one was that of Prime Minister Samak. The other was the government of Somchai Wongsawat, Thaksin's brother-in-law, who became prime minister after the PPP was dissolved by the decision made by the Constitutional Court and the Pheu Thai Party (PT). The second generation of Thaksin's proxy party then was immediately established. With the strong support of the military, small and medium parties (including the group of House of Representatives members that decided to defect from the PT to establish their own party; i.e. the Phumjai Thai Party: PTP), the leader of the Democrat Party, Abhisit Vejjajiva, was elected by the House of Representatives to be prime minister and to form a new government. $^{39}$

In the policy statement delivered by Prime Minister Abhisit to the parliament on December $30^{\text {th }}, 2008$, the word reconciliation, on the one hand, was similar to the use made of the term by the government in the policy statements of Surayud, Samak, and Somchai and appeared as one of the priorities and ultimate goals that 
the government aimed to achieve. On the other hand, the government of Abhisit added some new ideas (words) necessary for the implementation of the reconciliation policy. As the government stated, they would “...[p]romptly promote harmony and reconciliation among people in the nation by using peaceful means, listening to opinions from all sides and avoiding any use of violence as means of resolving national problems in all circumstances; restore social order and enforce law on the basis of equality and justice to all sides; and support the participation of organizations established pursuant to the Constitution in the process of reconciliation within the framework of each organization's mandate. ${ }^{40,}$

Nonetheless, when this policy statement was implemented, the election of Abhisit as new prime minister was immediately rejected by the pro-Thaksin movement, the Red Shirts. This rejection led to the two major protests launched by the Red Shirts that occurred in April $2009^{41}$ and April-May 2010. ${ }^{42}$ As a result of these two events, many Red Shirt leaders were put in jail, and others went into exile, but emotions were still painful. As a response to these political conflicts, the government of Abhisit appointed five independent committees to work towards the aims to establish reconciliation and to achieve political reform. ${ }^{43}$ Among these committees, the Truth for Reconciliation Commission of Thailand (TRCT), headed by Professor Kanit Nanakorn and eight other suitably-qualified commissioners, played a key role in: "[1] carrying out investigations and truth-seeking into the root causes of the problems, conflict, and violent clashes that occurred; [2] creating mutual understanding and determining solutions that would lead to the prevention of further violence and damage; and [3] promoting enduring reconciliation in the nation." 44 According to these core missions of the TRCT, the definition of reconciliation and international experience in conducting the reconciliation process, based on such a definition used in several countries, or as this research calls it, the third category of reconciliation meanings, was first introduced and adopted by the Thai government and its state agency as not only an end but also a means of bringing about peace and reconciliation to the country.

In adopting this category of the reconciliation concept, the TRCT announced the employment of the principles of transitional justice in its procedures and to modify those principles where necessary to suit Thailand's unique situation through the lessons learned from many countries that have experienced violent conflict and that were unable to use the normal system of justice to solve their problems. More specifically, the TRCT determined its strategy of operation consisting of the following four major activities. The first activity was investigation and truth-seeking, which refers to investigating the root causes of the conflict and violence that have occurred in the country in recent years, as well as seeking the truth and facts about the violence that occurred during April and May 2010. The second activity was related to the process of restoration, rehabilitation, and violence prevention. This activity involved the creation of understanding between the organizations, institutions, groups, and individuals that were affected by violent incidents. It was also an activity that used restorative and social justice in order to promote enduring national reconciliation in Thailand and the prevention of further violence and loss. The third activity was to conduct research that would clarify the root causes of the conflict in terms of the law, political situation, and historical events that influenced the division and violence in recent times. The final activity was in regard to drawing the lessons learned from the results found in the above three activities in order to report to the public and to recommend to the government what should be done for building reconciliation and preventing further violence. ${ }^{45}$

However, when the TRCT had worked for less than a year, Prime Minister Abhisit decided to dissolve the House of Representatives after amending the 93-98 and 190 of the 2007
Constitution according to the recommendations made by the Constitutional Reform Committee and determined the date for holding the general election on July $3^{\text {rd }}$, 2011. Unlike what Prime Minister Abhisit and his supporters expected, Yingluck Shinawatra, former Prime Minister Thaksin's youngest sister, and her PT, won the election by an absolute majority. Yingluck then became the first woman prime minister ever in Thai political history. In her policy statement delivered to the parliament on August $23^{\text {rd }}, 2011$, Prime Minister Yingluck announced that she would ensure that the TRCT would continue to act independently and would receive full cooperation from the government and all sides in carrying out verification and fact finding regarding cases of political violence, human rights violations, loss of life, physical and mental injury, and damage to property. ${ }^{46}$ The government would, according to her, follow the TRCT's recommendations to provide remedies to persons regardless of their positions or political ideologies, including ordinary people, protesters, government officers, and private sector entrepreneurs that had been affected by the violence that took place in the later period of the promulgation of the 1997 Constitution. ${ }^{47}$ Despite the reconciliation policies initiated by the government of Yingluck, the Ad Hoc Committee on National Reconciliation Building headed by General Sonthi Boonyaratglin, the former leader of the CDR who became a member of the House of Representatives after the 2011 election, also was established. This ad hoc committee comprised all parties to the conflict, including politicians from the government and opposition parties, Yellow and Red Shirt leaders, state officers involved in the conflict events, and representatives from other related agencies. One of the key jobs that this ad hoc committee intended to accomplish was to provide recommendations for reconciling the country with the government. Those recommendations mainly included the reconciliation process suggested by the research report conducted by King Prajadhipok's Institute, the national academic institution under the supervision of the President of the National Assembly.

According to the research conducted by King Prajadhipok's Institute, the term reconciliation was defined according to the meaning used by the TRCT as "the processes to rectify the past wrong and prevent further violence that may occurred in the future by constructing a peace-building process, stopping a violent circle, and revitalizing democratic institutions." 48 The report also clarified this concept by making an observation on the case of Thailand-that reconciliation is not an easily-implemented process.49 The implementation of a reconciliation policy in Thailand seems to be impossible without having the atmosphere of peace building and specifically, trust building, both in terms of institutional trust and trust among individuals.50 In this regard, the government and all of the people involved in the reconciliation process have to recognize that this process requires suitable, ongoing, and inclusive plans, procedures, and methods because it is related to many complicated activities, such as the creation of the people's attitude of forgiveness instead of revenge, management dealing with a shared history and memory about the violent events, the restoration of confidence in the judicial process, and so on. ${ }^{51}$

\section{Concluding Remarks}

To sum up, reconciliation in the Thai language and context is a term that has been dynamically interpreted, explained, and applied differently by policy makers, scholars, activists, and leaders of the conflicting groups. Many times, such an interpretation, explanation, and appliance have made this term a means to defeat the people of conflicting groups rather that a means of resolving the problems and reconciling the society. The Thai old style of reconciliation, especially enacting laws to enforce peace and to use a coup in order to stop violence, is still implemented by political leaders. As a result, 


\section{Proc. of the Sixth Intl. Conf. Advances in Social Science, Economics and Management Study - SEM 2018 Copyright $(\odot$ Institute of Research Engineers and Doctors, USA .All rights reserved. \\ ISBN: 978-1-63248-151-1 doi: 10.15224/978-1-63248-151-1-55}

the political conflicts in this country sometimes have been paused but have never been solved until the present.

More than three years after the most recent coup in 2014, the Thai society is still divided. The military government of General Prayut Chan-o-cha, the NCPO chairman, once again established a reconciliation committee working under the umbrella of the Committee for Reform, Reconciliation, and National Strategy. The good news is that this new reconciliation committee was created as a result of the government of Prayuth's awareness of the important of the creation of national unity in stimulating the national development. However, this new reconciliation committee was made up mostly of military officers and state officials with a minority of members with specialist experience in reconciliation and peace building. Concerns about the appliance of the Thai old style of reconciliation, particularly by enacting an amnesty law or using an authoritarian power to enforce peace is still in existed and widespread throughout the Thai society. An achievement in reconciling the decade-long political conflict in this country from the work of this committee therefore is questionable and perhaps hardly expected.

\section{References}

[1] Stout, David. 2013. "A primer on Thailand's color war: Why red hates yellow." Time, November 7. Retrieved from <http://world.time.com/ 2013/11/07/thailands-color-war-why-red-hatesyellow/> Accessed 23 January 2017

[2] Cavanagh, Roy. 2015. "Who are the Yellow Shirts and Red Shirts?" Thaizer,December 16. Retrieved from <http://www.thaizer.com/politics/who-are-the-yellow-shirts-and-red-shirts/> Accessed on 23 January 2017 .

[3] Ibid.

[4] Ibid.

[5] Ibid.

[6] Ockey, James. 2009. Thailand in 2008: Democracy and Street Politics. Southeast Asian Affairs 2009: 315-333

[7] Abhichart Sthitniramai. 2010. "Who Are the Red Shirts and Why Have They Come Out?" Matichon, 20 July 2010. Retrieved from <http://www.matichon.co.th/news_detail.php? newsid=1279607815\&grpid=01\&catid=(http://www.matichon.co.th/news_detail.php?newsid=12 79607815\&grpid=01\&catid=) Accessed on 23 January 2017; Chairat Charoensin-o-larn. 2010. Thailand in 2009: Unusual Politics Becomes Usual. Southeast Asian Affairs (2010): 302-331.

[8] See, Johan Galtung.1976. "Three Approaches to Peace: Peacekeeping, Peacemaking, and Peacebuilding," in Peace, War and Defense: Essays in Peace Research, Vol. II, ed. Johan Galtung (Copenhagen: Christian Ejlers,), 297-298.

[9] 9 Bloomfield, David, Teresa Barnes, and Luc Huyse. 2003. Reconciliation after Violent Conflict: A Handbook. Stockholm: International Institute for Democracy and Electoral Assistance.

[10] Ibid.

[11] Ibid.

[12] Abu-Nimer, Mohammed (ed.). 2001. Reconciliation, Justice, and Coexistence: Theory and Practice. Lanham, MD: Lexington Books.

[13] Galtung, Johan. 2001. "After violence, Reconstruction, Reconciliation, and Resolution: Coping with Visible and Invisible Effects of War and Violence," in Abu-Nimer, Mohammed (ed.), Reconciliation, Justice, and Coexistence: Theory and Practice, Lanham, MD: Lexington Books.

[14] Abu-Nimer, op. cit.; Bloomfield et al., op cit.

[15] Abu-Nimer, op. cit.; Weiner, Eugene (ed.). 1998. The Handbook of Interethnic Coexistence. New York: Continuum

[16] Bloomfield et al., op cit.

[17] Abu-Nimer, op. cit.; Bercovitch, Jacob, Victor Kremenyuk, and William I. Zartman (eds.). 2009. The SAGE Handbook of Conflict Resolution. London: Sage.

[18] Huyse, Luc. 1998. "Transitional Justice," in Peter Harris and Ben Reilly (eds.), Democracy and Deep-Rooted Conflict: Options for Negotiators, Stockholm: International IDEA.

[19] Emphasized by the author

[20] http://www.manager.co.th/mwebboard/listComment.aspx?QNumber=197374\&Mbrowse=9

[21] Emphasized by the author

[22] http://www.polyboon.com/stories/story000073.html
[23] Emphasized by the author

[24] http://www.polyboon.com/stories/story000073.html

[25] Emphasized by the author

[26] http://www.polyboon.com/stories/story000073.html

[27] Emphasized by the author

[28] http://km.rdpb.go.th/Knowledge/View/68

[29] See Rungtham Sujithammarak. B.E. 2545. Peace Studies and Peace. Class materials of Peace Studies and Peace subject, Unit 1. Nonthaburi: Sukhothai Thammatirat Open University.

[30] See Chaiyan Ratchakul. 2002. Conflicts in the Context of Peaceful Means. Class materials of Peace Studies and Peace subject, Unit 2. Nonthaburi: Sukhothai Thammatirat Open University.

[31] Policy Statement of the Council of Ministers Delivered by General Surayud Chulanont, Prime Minister of the Kingdom of Thailand to the National Legislative Assembly On Friday, 3 November 2006, pp. 14-15

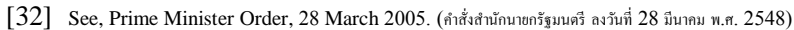

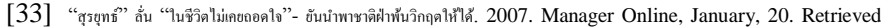
from 〈http://www.manager.co.th/Local/ViewNews.aspx?NewsID=9500000028081〉 Accessed on 14 February 2017.

[34] The week in review. 2006. Bangkok Post, October 1, p.4

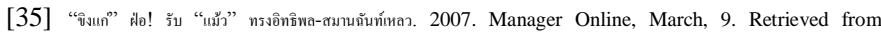
〈http://www2.manager.co.th/Politics/ViewNews.aspx?NewsID=9510000007838> Accessed on 14 February 2017.

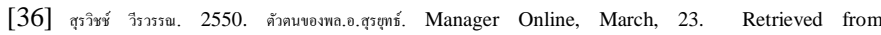
〈http://www.thaiday.com/Daily/ViewNews.aspx?NewsID=9500000033429〉 Accessed on 14 February 2017

[37] "Call to Amend Charter." The Nation, 22 March 2008, p. 1A.

[38] "Charter is not a political toy." Bangkok Post, 25 March 2008, p. 10.

[39] The Guardian, April 14, 2009

[40] Policy Statement of the Council of Ministers Delivered by Mr. Abhisit Vejjajiva, Prime Minister of the Kingdom of Thailand to the National Legislative Assembly On Friday, 30 December 2008,

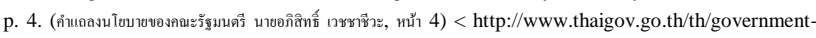

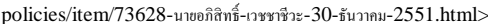

[41] Askew, Marc. 2010. "Confrontation and Crisis in Thailand, 2008-2010." In Legitimacy Crisis in Thailand, ed. Marc Askew. Bangkok: King Prajadhipok's Institute.

[42] Reuters, April 4, 2010

[43] These committees or working groups include the National Reform Committee, National Reform Assembly, Truth for Reconciliation Commission of Thailand (TRCT), Constitutional Reform Committee, and Working Group for Reforming the Media.

[44] The Truth for Reconciliation Commission of Thailand. 2012. Final Report of Truth for Reconciliation Commission of Thailand (TRCT) July 2010 - July 2012. Bangkok: The Truth for Reconciliation Commission of Thailand, p. iii.

[45] Ibid., p. 8.

[46] Policy Statement of the Council of Ministers Delivered by Ms. Yingluck Shinawatra, Prime Minister of the Kingdom of Thailand to the National Legislative Assembly On Friday, 23 August 2011, p. 5. Retrieved from < http://www.thaigov.go.th/th/government-policies/item/73629-

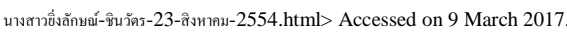

[47] Ibid, P.4

[48] King Prajadhipok's Institute. 2012. The National Reconciliation Building. Bangkok: King Prajadhipok's Institute, p. 18.

[49] Ibid., p. 27

[50] Ibid., pp. 27-29

[51] Ibid., p. 29-32 